\title{
The Effect of Cassia sieberiana Root Bark Extract on Various Experimental Gastric Ulcer Models in Rats
}

\author{
Nartey $\mathrm{ET}^{\mathrm{a} *}$, Addo $\mathrm{PG}^{\mathrm{b}}$, Ofosuhene $\mathrm{M}^{\mathrm{c}}$, Okine $\mathrm{LK}^{\mathrm{d}}$, Nyarko $\mathrm{AK}^{\mathrm{c}}$ \\ ${ }^{a}$ Centre for Tropical Clinical Pharmacology and Therapeutics, \\ University of Ghana Medical School, College of Health Sciences, \\ P.O. Box GP 4236, Accra, Ghana. \\ ${ }^{\mathrm{b}}$ Department of Animal Experimentation, Noguchi Memorial Institute for Medical Research, \\ College of Health Sciences, University of Ghana. \\ 'Department of Clinical Pathology, Noguchi Memorial Institute for Medical Research, \\ College of Health Sciences, University of Ghana. \\ ${ }^{\mathrm{d}}$ Department of Biochemistry, University of Ghana.
}

\begin{abstract}
The antiulcerogenic effects of the root bark extract of $C$. sieberiana were studied using various gastric ulcer models in rats. This was to support the rational phytotherapeutic use of Cassia sieberiana root bark extract in managing gastric ulcer. The cytoprotective ability of the extract was tested using the $\mathrm{HCl} /$ ethanol and the indomethacin- $\mathrm{HCl} /$ ethanol induced gastric lesion models. The healing ability of the extract was tested using the acetic acid induced model. Ulcer index, gastric $\mathrm{HCl}$ output, mucus production, pepsin activity and volume of gastric secretion were measured. Oral administration of the abstract $(500-1000 \mathrm{mg} / \mathrm{kg}$ body weight) inhibited the formation of gastric ulcers induced by $\mathrm{HCl} /$ ethanol $(19-61 \%)$. This inhibition was significantly $(\mathrm{p}<0.05)$ suppressed by pretreatment of the experimental rats with indomethacin $(30 \mathrm{mg} / \mathrm{kg}$ i.p). Oral administration of the extract in acetic acid induced ulcers produced significant dose-dependent healing of the gastric ulcers, significantly decreased total gastric $\mathrm{HCl}$ output and also significantly increased gastric barrier mucus production but these were not associated with changes in gastric secretion volume or pepsin activity.
\end{abstract}

Keywords: Cassia sieberiana; Antiulcer; Gastric cytoprotection

\section{Introduction}

Cassia sieberiana (Cassia kotschyana Oliv.; Fam. Caesalpinaceae) is a savannah tree common in drier areas of secondary forests and thickets. Its roots are widely used in African traditional medicine for the management of diseases including hernia and leprosy (1). At the Centre for Scientific Research into Plant Medicine (CSRPM) in Ghana, an aqueous suspension of the powdered root bark is used to manage abdominal colic and pains associated with the joints. Studies by Dadzie-Mensah (2) and Weremfo (3) indicate that the root extract exhibits both analgesic and anti-inflammatory properties. These earlier findings gave some indication of the pharmacological basis for the therapeutic action of the roots of $C$. sieberiana in the management of gastric ulcers by practitioners of traditional medicine in Ghana. This paper investigated the effect of $C$. sieberiana root bark extract on different models of gastric ulcer in rats by measuring the effect on ulcer index, gastric secretion volume, total gastric $\mathrm{HCl}$ output, pepsin activity and gastric barrier mucus production.

* Corresponding Author: Email: etnartey@chs.edu.gh 


\title{
Materials and Methods
}

\begin{abstract}
Animals
Pathogen free Fisher $344\left(\mathrm{~F}_{344}\right)$ rats weighing between $300 \mathrm{~g}$ and $350 \mathrm{~g}$ and 8 weeks old were used for the anti-ulcer studies. Five groups of male $\mathrm{F}_{344}$ rats made up of 5 rats per group were used in the study. Two of these groups served as controls as follows; the ulcer control and the cimetidine control. The other three groups served as the treatment groups receiving C. sieberiana extract 500, 750 and 1000 $\mathrm{mg} / \mathrm{kg}$ respectively.
\end{abstract}

\section{Preparation of plant extract}

Fresh roots of C. sieberiana (Cassia kotschyana Oliv.) were obtained from the grounds of the University of Ghana. The plant was identified and authenticated at the Ghana Herbarium, University of Ghana, Ghana. The chopped fresh root bark $(750 \mathrm{~g})$ were grounded and mixed with $1 \mathrm{~L}$ of water and left to stand overnight. The resulting concoction was evaporated under reduced pressure at $30^{\circ} \mathrm{C}$ and the concentrate freeze-dried to yield solid material. The freeze-dried root extract was stored at $4{ }^{\circ} \mathrm{C}$ and used within 4 weeks of production.

HCl/ethanol-induced gastric ulcers

Gastric mucosal ulcers were induced by the method of Hara and Okabe (4). Briefly, the rats were fasted for 48 hours followed by the oral administration of the different concentrations of the freezedried extract 500, 750 and $1000 \mathrm{mg} / \mathrm{kg}$ body weight, suspended in distilled water (as vehicle) in a total volume of $2.0 \mathrm{~mL}$ respectively. The ulcer control group received $2 \mathrm{~mL}$ of the vehicle whilst the cimetidine control group received $32 \mathrm{mg} / \mathrm{kg}$ cimetidine. The $\mathrm{HCl} /$ ethanol solution $(150 \mathrm{mM} \mathrm{HCl}$ in $60 \% \mathrm{v} / \mathrm{v}$ ethanol) in a total volume of $1 \mathrm{~mL}$ was orally administered $1 \mathrm{~h}$ later after extractor vehicle or cimetidine administration. The rats were euthanized $1 \mathrm{~h}$ later, and the stomachs removed and opened along the greater curvature and the ulcers graded according to the method of Marhueda et al. (5).

\section{HCl/ethanol-induced gastric ulcers in rats pre-treated with indomethacin}

The protective effect of the root bark extract against $\mathrm{HCl}$ /ethanol induced ulcers after pre-treatment with indomethacin was done as described by Sun et al. (6). Briefly, all the rats received intraperitonealy $30 \mathrm{mg} / \mathrm{kg}$ indomethacin $1 \mathrm{~h}$ prior to receiving the root bark extract/vehicle/cimetidine. One hour after the administration of the various concentrations of the plant extract/vehicle/cimetidine as described in 2.3, all the animals were orally given $1 \mathrm{~mL}$ $\mathrm{HCl} /$ ethanol solution. The rats were euthanized $1 \mathrm{~h}$ later, the stomachs removed and opened along the greater curvature and the ulcers graded according to the method of Marhueda et al. (5).

Acetic acid (necrotising agent) induced gastric ulcers in rats

Based on earlier preliminary studies, the experimental design for acetic acid ulcer induction was by oral gavage of a single dose of $1.0 \mathrm{M}$ acetic acid in male $\mathrm{F}_{344}$ rats $(1.5 \mathrm{~mL} / \mathrm{kg}$ body weight). The rats were fasted for 12 hours but maintained on water ad libitum which was also removed 3 hours prior to the experimentation where $1.5 \mathrm{~mL} / \mathrm{kg} 1.0 \mathrm{M}$ acetic acid were administered to each rat. Water and food were re-introduced three hours after the administration of acetic acid. Different concentrations of the freeze-dried extract 500,750 and $1000 \mathrm{mg} / \mathrm{kg}$ body weight, suspended in distilled water (as vehicle) in a total volume of $2.0 \mathrm{~mL}$ were administered orally to the groups respectively 24 hours after acetic acid administration. The ulcer control and cimetidine control groups also received the vehicle or cimetidine respectively. Treatment was repeated every 24 hours for 7 consecutive days. After final treatment with extract, vehicle or cimetidine on day 7 , each rat was euthanized by cervical dislocation and the stomach removed. The stomach was cut open along the greater curvature, observed for mucosal lesions and graded according to the method of Marhueda et al. (5). 


\section{Estimation of gastric barrier mucus}

The gastric barrier mucus of each dissected stomach (after ulcer index determination in 2.5) was quantitatively estimated by the method of Corne et al. (7).

Gastric juice sampling for total gastric HCl output and pepsin activity

In another set of experiments, five new groups of male $\mathrm{F}_{344}$ rats made up of two control groups (ulcer control and cimetidine control) and three treatment groups $(500,750$ and $1000 \mathrm{mg} / \mathrm{kg}$ ) of the extract were treated as in section 2.5. After euthanasia, the pyloric and oesophageal ends of the stomach were ligated and the stomach removed. The gastric content was drained and centrifuged at $1000 \mathrm{~g}$ for 10 min at $4{ }^{\circ} \mathrm{C}$ to obtain a clear solution (gastric secretion) and the volume measured. A total of $1 \mathrm{~mL}$ of the gastric secretion was assayed for hydrogen ion concentration by titrating with $0.01 \mathrm{M} \mathrm{NaOH}$ and the total gastric output expressed as micro-equivalent of $\mathrm{HCl}$ (Eq). Pepsin activity of the gastric juice was determined by the method of Anson ( 8 ) and expressed as $\mu \mathrm{mol}$ tyrosine $/ \mathrm{mL} / \mathrm{min}$.

\section{Statistical analysis}

Comparisons between treatment means were performed using Analysis of Variance (ANOVA) followed by Student's Standard Newman-Keuls post-hoc analysis to determine statistical significance. The 0.05 level of probability was used as the criteria of significance in all instances. Values are expressed as arithmetic means \pm standard error of the mean (SEM).

\section{Results}

Table 1: Effect of root bark extract of $C$. sieberiana on $\mathrm{HCl} /$ ethanol-induced gastric ulcers in $\mathrm{F}_{344}$

\begin{tabular}{lll}
\hline Treatments & Dose $(\mathrm{mg} / \mathrm{kg})$ & Ulcer index (Mean \pm S.E.M) \\
\hline Ulcer control & vehicle & $7.20 \pm 0.20$ \\
Extract & 500 & $5.80 \pm 0.37^{\mathrm{a}}$ \\
Extract & 750 & $4.40 \pm 0.24 \mathrm{~b}$ \\
Extract & 1000 & $2.80 \pm 0.20^{\mathrm{b}}$ \\
Cimetidine & 32 & $2.60 \pm 0.24 \mathrm{~b}$ \\
\hline
\end{tabular}

${ }^{a} \mathrm{p}<0.05$, statistically significant relative to ulcer control

${ }^{\mathrm{b}} \mathrm{p}<0.001$, statistically significant relative to ulcer control

Table 1 above shows that different concentrations of the root bark extract $(500-1000 \mathrm{mg} / \mathrm{kg}$ ) offered significant dose-dependent cytoprotection of the stomach mucosa against $\mathrm{HCl} /$ ethanol solution. There were $19 \%, 39 \%$ and $62 \%$ protection in the 500,750 and $1000 \mathrm{mg} / \mathrm{kg}$ groups respectively. Cytoprotection was $65 \%$ in the cimetidine control group. 
Table 2: Effect of root bark extract of $C$. sieberiana on $\mathrm{HCl} /$ ethanol-induced gastric ulcers in $\mathrm{F}_{344}$ rats pretreated with indomethacin

\begin{tabular}{lll}
\hline Treatments & Dose $(\mathrm{mg} / \mathrm{kg})$ & Ulcer index $($ Mean \pm S.E.M) \\
\hline Ulcer control & vehicle & $7.80 \pm 0.20$ \\
Extract & 500 & $7.00 \pm 0.32^{\mathrm{a}}$ \\
Extract & 750 & $6.20 \pm 0.37^{\mathrm{b}}$ \\
Extract & 1000 & $5.40 \pm 0.40^{\mathrm{c}}$ \\
Cimetidine & 32 & $3.00 \pm 0.32^{\mathrm{c}}$ \\
\hline
\end{tabular}

\footnotetext{
${ }^{\mathrm{a}} \mathrm{p}<0.05$, statistically significant relative to ulcer control

${ }^{\mathrm{b}} \mathrm{p}<0.01$, statistically significant relative to ulcer control

${ }^{c} \mathrm{p}<0.001$, statistically significant relative to ulcer control
}

The inhibitory effect of the extract against $\mathrm{HCl} /$ ethanol solution was significantly $(\mathrm{p}<0.05)$ suppressed (between 21\% and 93\%) when the rats were pre-treated with indomethacin (Table 2). Pre-treatment with indomethacin also reduced the cytoprotection of cimetidine against $\mathrm{HCl} / \mathrm{ethanol}$ solution but this was not significant $(\mathrm{p}>0.05)$.

Table 3: Effect of root bark extract of C. sieberiana on acetic-acid induced gastric ulcers in $\mathrm{F}_{344}$ rats

\begin{tabular}{lll}
\hline Treatments & Dose $(\mathrm{mg} / \mathrm{kg})$ & Ulcer index $($ Mean \\
\hline Ulcer control & vehicle & $7.00 \pm 0.71$ \\
Extract & 500 & $4.20 \pm 0.20^{\mathrm{a}}$ \\
Extract & 750 & $3.40 \pm 0.24^{\mathrm{a}}$ \\
Extract & 1000 & $2.40 \pm 0.24^{\mathrm{b}}$ \\
Cimetidine & 32 & $2.00 \pm 0.32^{\mathrm{b}}$ \\
\hline
\end{tabular}

${ }^{a} \mathrm{p}<0.01$, statistically significant relative to ulcer control

${ }^{\mathrm{b}} \mathrm{p}<0.001$, statistically significant relative to ulcer control

Table 3 shows that daily administration of the extract for 7 days produced significant dose-dependent healing of gastric ulcers. There was $40 \%, 51 \%$ and $66 \%$ healing in the 500,750 and $1000 \mathrm{mg} / \mathrm{kg}$ groups respectively. Healing was $71 \%$ in the cimetidine group. 
Table 4: Effects of root bark extract of C. sieberiana on total gastric $\mathrm{HCl}$ output in $\mathrm{F}_{344}$ rats

\begin{tabular}{lll}
\hline Treatment & Dose $(\mathrm{mg} / \mathrm{kg})$ & $\begin{array}{c}\text { Gastric HCloutput }(\mu \mathrm{Eq}) \\
(\text { Mean } \pm \text { S.E.M })\end{array}$ \\
\hline Ulcer control & vehicle & $271.4 \pm 11.2$ \\
Extract & 500 & $217.1 \pm 8.5^{\mathrm{a}}$ \\
Extract & 750 & $184.6 \pm 9.6^{\mathrm{b}}$ \\
Extract & 1000 & $173.9 \pm 10.4^{\mathrm{b}}$ \\
Cimetidine & 32 & $147.2 \pm 8.2^{\mathrm{b}}$ \\
\hline
\end{tabular}

${ }^{a} \mathrm{p}<0.01$, statistically significant relative to ulcer control

${ }^{\mathrm{b}} \mathrm{p}<0.001$, statistically significant relative to ulcer control

Daily administration of the root extract for 7 days produced a significant dose-dependent reduction of total gastric $\mathrm{HCl}$ output by $20 \%, 32 \%$ and $36 \%$ respectively for rats treated with 500, 750 and 1000 $\mathrm{mg} / \mathrm{kg}$ body weight of the extract (Table 4 ). Cimetidine also significantly decreased total gastric $\mathrm{HCl}$ output by $46 \%$ compared to the ulcer control group.

Table 5 below shows that extract administration increased gastric barrier mucus production in a dosedependent manner. Compared to the ulcer controls the observed mucus production increased by $25 \%, 35 \%$, and $40 \%$ for rats treated with 500,750 and $1000 \mathrm{mg} / \mathrm{kg}$ body weight of the extract respectively. Cimetidine also significantly increased gastric barrier mucus production by $44 \%$ compared to the ulcer control group. Compared to the ulcer controls, there were no significant changes in volume of gastric secretions or pepsin activity (data not shown).

Table 5: Effects of root bark extract of C. sieberiana on total gastric barrier mucus production in $\mathrm{F}_{344}$ rats

\begin{tabular}{lcc}
\hline Treatment & Dose $(\mathrm{mg} / \mathrm{kg})$ & $\begin{array}{c}\text { \% Gastric mucus production } \\
(\text { Mean } \pm \text { S.E.M })\end{array}$ \\
\hline Ulcer control & vehicle & $29.5 \pm 1.5$ \\
Extract & 500 & $36.9 \pm 1.2^{\mathrm{a}}$ \\
Extract & 750 & $39.8 \pm 1.3^{\mathrm{a}}$ \\
Extract & 1000 & $41.4 \pm 1.2^{\mathrm{a}}$ \\
Cimetidine & 32 & $42.5 \pm 1.3^{\mathrm{a}}$ \\
\hline
\end{tabular}

${ }^{\mathrm{a}} \mathrm{p}<0.01$, statistically significant relative to ulcer control 


\section{Discussion and Conclusions}

\section{Discussion}

The present study was undertaken to investigate the antiulcerogenic effect, if any, of the root bark extract of $C$. sieberiana, which is used by herbalists in Ghana in the management of stomach disorders including gastric ulcer. Gastric ulcer disease is a multi-factorial disease but the main underlying factor is the role played by gastric $\mathrm{HCl}(9)$.

The $\mathrm{HCl} /$ ethanol method of inducing gastric lesions is a rapid and convenient way of screening plant extracts for their cytoprotection and antiulcer activity. The screening showed that the root back extract of $C$. sieberiana is a dose-dependent potent protector of the gastric mucosa against $\mathrm{HCl} /$ ethanol solution. However, this cytoprotection was significantly reduced when the experimental animals were pre-treated with indomethacin, a prostaglandin inhibitor. Indomethacin suppresses gastroduodenal bicarbonate secretion, disrupts the mucosal barrier, reduced endogenous prostaglandin biosynthesis as well as reduces gastric mucosal blood flow $(10,11,12)$. Conversely the role of prostaglandins in gastric mucosal protection has been extensively studied $(11,13,14,15)$. Prostaglandins inhibit the secretion of gastric acid, stimulate the secretion of mucus and bicarbonate in the stomach and help maintain the integrity of the gastric mucosa by enriching the mucusbicarbonate unstirred gel matrix in protecting the gastric mucosa (16). When the cytoprotective effect of an antiulcer agent is significantly reduced by pre-treatment with indomethacin, then the cytoprotection is interpreted as being mediated by endogenous prostaglandins (17) as it is with the root bark extract of $C$. sieberiana. The increased gastric barrier mucus production by $C$. sieberiana suggests that the root extract facilitates mucus production.

Oral administration of $C$. sieberiana dose-dependently decreased the number and severity of gastric ulcers in acetic acid induced gastric ulcer experimental rats which was comparable to cimetidine suggesting that $C$. sieberiana promotes the healing of acetic acid induced gastric ulcers. Further examination showed that both C. sieberiana and cimetidine which is an antagonist of histamine $\mathrm{H}_{2}$ receptors on the gastric mucosa parietal cell and an anti-secretory agent (18) significantly decreased total gastric $\mathrm{HCl}$ output which showed a close correlation with the ulcer healing effect of the extract. Antagonism of histamine $\mathrm{H}_{2}$ receptors would be expected to decrease gastric volume. In this study, cimetidine decreased gastric volume by $13 \%$ compared to only $2 \%$ by C. sieberiana at $1000 \mathrm{mg} / \mathrm{kg}$ body weight. These observations suggest that $C$. sieberiana may not be acting through histamine $\mathrm{H}_{2}$ receptor antagonism. Rather, the observed effects appear to be similar to a proton pump inhibitor. The proton pump, $\mathrm{H}^{+} / \mathrm{K}^{+}$-ATPase of the apical membrane of the gastric cell is the ultimate mediator of acid secretion (18). Therefore, $C$. sieberiana extract may contain anti-secretory agents that may be inhibitors of the proton pump and have little or no antagonism of histamine $\mathrm{H}_{2}$ receptors.

\section{Conclusions}

In conclusion, the root bark extract of $C$. sieberiana significantly offered cytoprotection against $\mathrm{HCl} /$ ethanol solution and decreased the number of gastric ulcers induced by acetic acid. It also decreased total gastric $\mathrm{HCl}$ output and increased gastric barrier mucus production without altering the volume of gastric secretion or pepsin activity. These findings taken together indicate that the extract may exert its anti-ulcer activity possibly through inhibition of gastric proton pump and cytoprotection via its anti-inflammatory prostaglandin stimulation. Efforts are underway to perform activity guided fractionation to isolate the active component(s) and study the activity profile of this compound(s) on histamine $\mathrm{H}_{2}$ receptors and the $\mathrm{H}^{+} / \mathrm{K}^{+}$-ATPase proton pump as well as its antimicrobial effect on $H$. pylori. 


\section{Acknowledgment}

We gratefully acknowledge the technical and administrative staff of the Animal Experimentation Unit of NMIMR, particularly Dr. Adu and Mr. Appiah for their assistance and cooperation.

\section{References}

1. Abbiw, D.K. (1990). Portions and Medicine. In: Useful plants of Ghana, pp. 118-205, Intermediate Technology Publications, London.

2. Dadzie-Mensah, J. (2000). Modulation of eicosanoids biosynthesis in vivo as a mechanism-based evaluation of putative anti-inflammatory plant extracts. MPhil thesis, University of Ghana, Ghana.

3. Weremfo, A. (2003). Analgesic, anticolitic and toxicological evaluation of root extract of Cassia sieberiana (fam. Caesalpinaceae) in rats. MPhil thesis, Kwame Nkrumah University of Science and Technology, Ghana.

4. Hara, N. and Okabe, S. (1985). Effect of gefernate on acute lesions in rats. Folia Pharmacologica japonica, 85: 443-448.

5. Marhueda, E., Martin, M. J. and Alarcon de lastra, C. (1993). Antiulcerogenic activity of aescine in different experimental models. Phytotherapy Research, 7: 13-16.

6. Sun, Z., Matsumoto, T. and Yamada, H. (1992). Anti-ulcer activity and mode of action of polysaccharide fraction from the leaves of Panax ginseng. Planta Medica, 58:432-435.

7. Corne, S.J., Morrissey, S.M. and Woods, R.J. (1974). A method for the quantitative estimation of gastric barrier mucus. Journal of Physiology (Proceedings of the Physiological Society), 242 (2): 116-117.

8. Anson, M.L. (1938). Estimation of pepsin, trypsin, papain and cathepsin with haemoglobin. Journal of General Physiology, 106: 79-89.

9. Lee, A. (2000). Animal models of gastroduodenal ulcer disease. Baillière's Clinical Gastroenterology, $14(1): 75-96$.

10. Selling, J.A., Hogan, D.L., Aly, A., Koss, M.A. and Isenberg, J.I. (1987). Indomethacin inhibits duodenal bicarbonate secretion and endogenous prostaglandin $\mathrm{E}_{2}$ output in human subjects. Annals of Internal Medicine, 106:38-371.

11. Miller, T.A. (1982). Protective effect of prostaglandins against gastric mucosal damage: Current knowledge and proposed mechanisms. American Journal of Physiology, 245: G601-G623.

12. Flemstrom, G., Garner, A., Nylander, O., Hurstt, B.C. and Heylings, J.R. (1982). Surface epithelial HCO3 transport by mammalian duodenum in vivo. American Journal of Physiology, 243: G348-G358.

13. Robert, A., Nezamis, J.E., Lancaster, C., Davies, J.P., Field, S.O. and Hanchar, A.J. (1983). Mild irritants prevent gastric necrosis through 'adaptive cytoprotection' mediated by prostaglandins. American Journal of Physiology 245: G113-G121.

14. Konturek, S.J., Piastucki, I., Brozozowski, T., Dembinska-Kiec, T.R.A., Muda, A. and Gryglewski, R. (1981). Role of prostaglandin in the formation of aspirin-induced ulcers. Gastroenterology, 80: 4-9.

15. Konturek, S.J., Brozozowski, T., Piastucki, I., Radecki, T., Dembinska, A. and Dembinskia-Kiec, A. (1982). Role of locally generated prostaglandin in adaptive cytoprotection. Digestive Diseases and Science, 27: 967-971.

16. Jason, D. M. and Jackson Roberts II, L. (2001). Lipid-derived autacoids: eicosanoids and plateletactivating factor. In: Goodman and Gilman's- The pharmacological basis of therapeutics. Hardman, J.G., Limbird, L.E. (eds., McGraw-Hill, New York. ), pp. 669-686

17. Yamamoto, K., Kakegawa, H., Veda, H., Matsumoto, H., Sudo, T., Miki, T. and Satoh, T. (1991). Gastric cytoprotective antiulcerogenic actions of hydroxychalcones in rats. Planta Medica, 58: 389-393.

18. Hoogerwerf, W. A. and Pasricha, P. J. (2001). Agents used for control of gastric acidity and treatment of peptic ulcers and gastroesophageal reflux disease. In: Goodman and Gilman's- The pharmacological basis of therapeutics. Hardman, J.G., Limbird, L.E. (eds, McGraw-Hill, New York. ), pp. 1005-1020. 